\title{
Effects of coumaphos on queen rearing in the honey bee, Apis mellifera ${ }^{1}$
}

\author{
Jeffery S. PetTis ${ }^{a *}$, Anita M. COLLins ${ }^{\mathrm{a}}$, Reg. WiLBANKS ${ }^{\mathrm{b}}$, Mark. F. FeLdLAUFER ${ }^{\mathrm{a}}$ \\ ${ }^{a}$ USDA, Agricultural Research Service, Bee Research Laboratory, Bldg. 476, BARC-East, Beltsville, \\ Maryland 20705, USA \\ b Wilbanks Apiaries, Claxton, Georgia 30417, USA
}

(Received 3 November 2003; revised 11 February 2004; accepted 26 February 2004)

\begin{abstract}
Young honey bee larvae were transferred into the queen cups containing known concentrations ( 0 to $1000 \mathrm{mg} / \mathrm{kg}$ ) of the organophosphate pesticide coumaphos. These larvae were placed in queenless colonies and examined ten days later to determine the rate of rejection or acceptance as indicated by a mature sealed queen cell. All queens failed to develop at $1000 \mathrm{mg} / \mathrm{kg}$, and greater than $50 \%$ of the queen cells were rejected at the $100 \mathrm{mg} / \mathrm{kg}$ concentration. Additionally, queens that survived exposure to $100 \mathrm{mg} / \mathrm{kg}$ coumaphos weighed significantly less than control queens. The implications of exposure of developing queens to sublethal amounts of pesticides are discussed.
\end{abstract}

coumaphos / queen rearing / residues / beeswax

\section{INTRODUCTION}

Beekeepers have relied upon the use of chemical compounds to protect their honey bee colonies from the parasitic mite Varroa destructor Trueman \& Anderson. However, the increased use of chemicals for parasitic mite control has coincided with increased beekeeper complaints of problems associated with maintaining productive queens in their colonies (Sanford, 2001). Recent research (Haarmann et al., 2002) has indicated that both fluvalinate and coumaphos have adverse effects on the queen rearing process when they were applied in the commercially available strip forms that each contain $10 \%$ active ingredient. Earlier research had indicated that both fluvalinate (Sokol, 1996) and coumaphos (Wallner, 1999) were persistent within bee colonies and thus could poten- tially impact the ability of colonies to rear their own queens. Continued beekeeper complaints of rapid queen supersedure following queen introduction and of the inability of colonies to naturally re-queen themselves provided the impetus for the current study. We decided to focus the study on the effects of coumaphos in beeswax on queen production as it had been demonstrated to be more toxic to honey bees than fluvalinate (Haarmann et al., 2002).

Queen honey bees are reared commercially in cups fashioned from beeswax that are placed in queenless colonies to be reared into mature queen cells, a sealed wax cell containing a queen in the late pupal stage (Laidlaw and Page, 1997). Haarmann et al. (2002) demonstrated that the beeswax in the queen cell tended to accumulate more pesticide as the wax queen cells are being built as higher concentrations were

\footnotetext{
${ }^{1}$ Disclaimer: Mention of trade names or commercial products in this article is solely for the purpose of providing specific information and does not imply recommendation or endorsement by the US Department of Agriculture.

* Corresponding author: pettisj@ba.ars.usda.gov
} 
found in the completed wax queen cells than in the surrounding beeswax. This indicates that nurse bees may play an important role in the transfer of compounds to the wax queen cup and the developing queen. The experimental protocol of Haarmann et al. (2002) did not allow discrimination between the role of pesticides circulating on the nurse bees from effects caused by the pesticides in the beeswax queen cup alone.

The accumulation of pesticides in beeswax within managed honey bee colonies can result from either the application of compounds within the colony (Sokol, 1996; Wallner, 1999; Floris et al., 2001) or by the accumulation of compounds in beeswax cells as bees forage and then deposit pollen and nectar within the hive (Anderson and Wojtas, 1986). We decided to examine one compound, coumaphos, in detail by testing a range of known concentrations in beeswax queen cups for effects on queens reared in these cups. The objective of this study was to determine the level of coumaphos needed in beeswax to adversely affect queen rearing and to begin to explore the potential for sublethal effects of miticides on queen honey bees.

\section{MATERIALS AND METHODS}

The effect of coumaphos in beeswax queen cups was tested by grafting worker larvae into wax cups containing known concentrations of coumaphos and determining the acceptance or rejection of grafted larvae. Initial experiments were carried out in Beltsville, Maryland and a final larger trial was conducted in a commercial queen rearing operation in Claxton, Georgia, USA. The queen rearing methodology employed followed closely that described by Laidlaw and Page (1997) in that worker larvae were transferred from the comb in which the eggs were laid into larger beeswax cups placed in an inverted manner into a queenless colony. The initial trails in Maryland used a queenless colony to both start and finish the queen cells over ten days. The commercial trail in Georgia used a starter colony (swarm box, Laidlaw and Page, 1999) for a $24 \mathrm{~h}$ period to "start" the cells. The cells were then removed and scored for acceptance and placed into finisher colonies that were queenright in the lower brood chamber (standard Langstroth) but used a queen excluder to allow for queen cells to be reared in the upper chamber. All colonies used in these studies were strong with regard to bee population, had been previously treated for $V$. destructor and were apparently free of other bee diseases.

\subsection{Beeswax queen cups}

Beeswax queen cups were made by collecting naturally produced beeswax from two colonies that had been established in new wooden hives with no foundation for the express purpose of producing uncontaminated beeswax. This wax was analyzed by gas chromatography-mass spectrometry (GC-MS; see below) and found to be free of fluvalinate and coumaphos, the two legal pesticides used in the U.S. to control V. destructor. Technical grade coumaphos (Bayer, Shawnee Mission KS) was recrystallized from methyl tert- butyl ether and a stock $1000 \mathrm{mg} /$ $\mathrm{kg}$ solution made by mixing $100 \mathrm{mg}$ of coumaphos into $100 \mathrm{~g}$ beeswax (at $65^{\circ} \mathrm{C}$ ). Subsequent concentrations were made by dilution with additional wax to produce concentrations of $1,10,100,300$ and $600 \mathrm{mg} / \mathrm{kg}$. Queen cups were made using individual wooden dowels ( $9 \mathrm{~mm}$ in diameter) that had been rounded on the bottom to produce an acceptable cup for queen rearing. The dowels were dipped in heated and stirred mixtures of treated wax to ensure uniformity of the coumaphos in the wax cell cups. Queen cups made from wax with no coumaphos served as controls $(0 \mathrm{mg} / \mathrm{kg})$. All cups were kept separate by concentration in plastic bags prior to being attached to wooden bases for the grafting process. New wooden queen cell bases (W.T. Kelly Co. Clarkson, Kentucky) were used that allowed the treatments to be marked directly on the wooden base in code such that subsequent grafting and acceptance rates were conducted blind with regard to treatment.

\subsection{Gas chromatography/mass spectrometry}

\subsubsection{Sample preparation}

All solvents used were B \& J Brand High Purity Solvents (Allied Signal, Burdick \& Jackson, Muskegon, MI). A sample ( 2 $\mathrm{g}$ ) of beeswax was placed in a $125 \mathrm{~mL}$ Erlenmeyer flask, $32 \mathrm{~mL}$ hexane and $25 \mathrm{~mL} 0.03 \mathrm{~N} \mathrm{HCl}$ was added and the material was heated at $40{ }^{\circ} \mathrm{C}$ with stirring until the wax was completely dissolved. The contents were poured into a $60 \mathrm{~mL}$ separatory funnel and the lower (aqueous) phase was drawn off and discarded. The hexane phase was extracted three times with acetonitrile (20 $\mathrm{mL}$ each). The acetonitrile phases were partitioned against $20 \mathrm{~mL}$ hexane in a second funnel. The combined acetonitrile phases were evaporated to dryness under vacuum, then transferred to a vial with benzene, blown dry with $\mathrm{N}_{2}$ and redissolved in $100 \mu \mathrm{l}$ benzene. The sample was fractionated over a 
Waters Silica Sep-Pak (Waters Corp., Milford, MA) which had been pre-conditioned with $5 \mathrm{~mL}$ hexane (fraction \#1, $3 \mathrm{~mL}$ hexane; fraction \#2, $5 \mathrm{~mL} \mathrm{20 \%}$ diethyl ether in hexane). Fraction \# 2 was blown dry under nitrogen and re-dissolved in $100 \mu$ l benzene for analysis.

\subsubsection{Analyses and instrumentation}

One $\mu \mathrm{L}$ of fraction \#2 was analyzed by gas chromatography-mass spectrometry (GC-MS), performed on a Finnigan GCQ (electron impact spectra at $70 \mathrm{eV}$; source temperature $165^{\circ} \mathrm{C}$; Thermo; Finnigan, San Jose, CA) fitted with an on-column injector (J \& W Scientific, Folsom, CA) equipped with a Restek Rtx - 5MS fused silica column (30 $\mathrm{m} \times$ $0.25 \mathrm{~mm} ; 0.25 \mu \mathrm{m}$ df; 19 psi head pressure; Restek Corp., Bellefonte, PA), temperature programmed $\left(60{ }^{\circ} \mathrm{C}, 1 \mathrm{~min}\right.$ then increased $20^{\circ} \mathrm{C} / \mathrm{min}$ to $270{ }^{\circ} \mathrm{C}$, hold $38.5 \mathrm{~min}$ ). The presence (or absence) and amount of pesticide was determined by comparison of retention time and characteristic ions (m/z: coumaphos 362, 334, 306; fluvalinate 502, 252, 250; amitraz 293, 162,147) with that of known quantities of authentic standards. Blank injections were made between each sample.

\subsection{Maryland study}

A series of queen grafting trials were conducted in Beltsville, MD to determine the target doses to be used in subsequent commercial queen rearing conditions. The trials in Beltsville involved the grafting of young larvae into the entire coumaphos dose series and determining the acceptance rates of queens at ten days post-grafting. The seven doses of coumaphos tested were $0,1,10,100,300,600$, and $1000 \mathrm{mg} / \mathrm{kg}$. This study employed the use of a single, queenless colony to both start and finish the queen cells over a ten-day period. A wooden frame was modified to hold three grafting bars of 14 cups each. Each test consisted of 42 cups (three bars) grafted on each of four dates in April and June 2002. Thus six replicates of each treatment were tested in each of the four trails for a total of 24 queen cups per treatment; individual treatment cups were randomly placed along each bar in groups of seven. Queen acceptance was scored by removing all cells from the colony ten days post-grafting, noting acceptance by treatment, and carefully opening and weighing all mature queens.

\subsection{Commercial study}

Based on the Maryland study, the 300 and $600 \mathrm{mg} / \mathrm{kg}$ concentrations were eliminated from further testing to allow us to test specific doses with higher replicate numbers in a commercial queen rearing operation. Studies with $0,1,10,100$ and $1000 \mathrm{mg} / \mathrm{kg}$ of coumaphos in beeswax cups were carried out at Wilbanks Apiaries Inc., Claxton GA, in July 2002. Larvae were grafted from a single queen source into a total of 576 wax queen cups. Each grafting bar contained 16 cups all of the same treatment to avoid potential cross contamination issues. Four queenless starter colonies were used with each starter colony receiving 144 grafted cups. Twentyfour hours later the cells were removed and initial acceptance scored. Wax cups that showed signs of new beeswax being drawn out and had a larva present were scored as an accepted cell. The cells were then randomly placed into "finisher" colonies for the next nine days. A total of 12 finisher colonies were used with each receiving bars of cells from only three treatment groups. On the tenth day following grafting, cells were removed and scored for acceptance. An accepted cell was one that was drawn out and sealed, while a rejected cell included those either rejected after $24 \mathrm{~h}$ or subsequently torn down late in the queen rearing process. Unequal sample sizes were employed as we anticipated $100 \%$ rejection in the $1000 \mathrm{mg} / \mathrm{kg}$ group (positive control) and ca. 50\% rejection in the $100 \mathrm{mg} / \mathrm{kg}$ group. A total of 112 cups were grafted in each of the 0 (negative control), 1 and $10 \mathrm{mg} / \mathrm{kg}$ coumaphos treatment groups; only 64 cells were grafted in the $1000 \mathrm{mg} / \mathrm{kg}$ treatment and 176 cells were grafted in the $100 \mathrm{mg} / \mathrm{kg}$ group as we required a minimum of 60 mature queen cells to be produced and placed in mating nuclei for the second phase of these studies designed to examine supersedure rates. Grafting was conducted on 9 July with final queen cells scored on 18 July. Extra queen cells (any cells more than 60 within a treatment) available in each group were taken back to Beltsville, MD, where queens were removed from their cells and weighed on 19 July.

\subsection{Statistical analyses}

The percentage of queens rejected in each treatment group was compared to the control group using a $2 \times 2$ contingency table and Chi-square Test or Fisher's Exact Test when cell counts fell below five (SAS, 1988). Potential differences in queen weights by each coumaphos treatment were tested using a Students $t$-test (SAS, 1988) to compare with the weights of untreated control queens.

\section{RESULTS}

\subsection{Maryland study}

The use of beeswax queen cups containing 300,600 or $1000 \mathrm{mg} / \mathrm{kg}$ of coumaphos resulted 


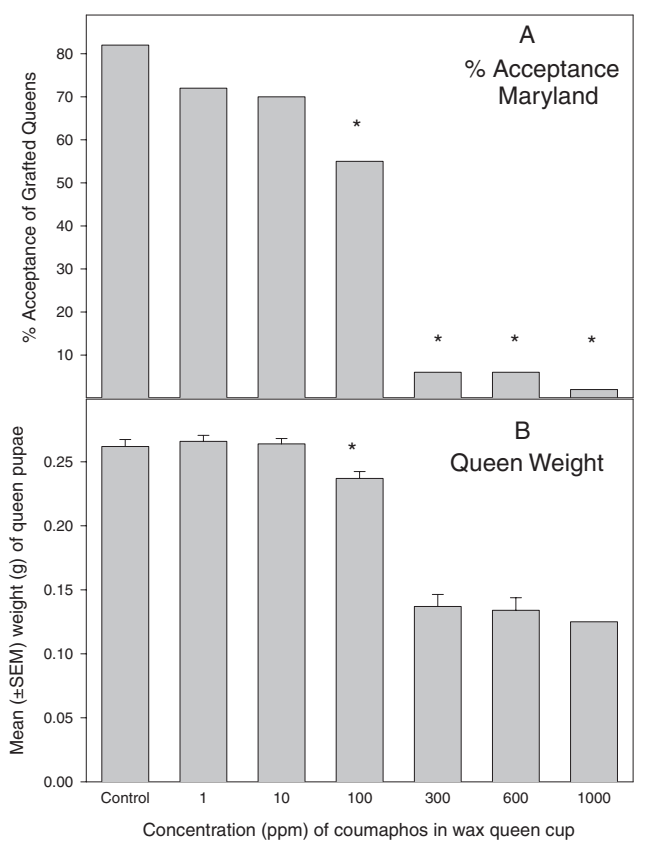

Figure 1. The percent acceptance (A) and weight (B) of pre-emergent queen honey bees reared in wax queen cups containing known concentrations of coumaphos. A total of twenty four replicate cups per treatment were tested over four trails in April and June 2002, Beltsville, Maryland. * indicates significant differences from the control group $(P<0.05)$.

in significant (Fisher' Exact Test, $P<0.001$ ) and nearly complete rejection of grafted larvae (Fig. 1a). From these three treatments only five queens completed development from the 72 grafted $(6.9 \%)$ compared to $85 \%$ of queens in the untreated control group and these five queens had a average weight of only $132 \mathrm{mg}$ compared to $270 \mathrm{mg}$ for untreated queens. Queens reared in cups containing $100 \mathrm{mg} / \mathrm{kg}$ had a significantly higher rejection rate (Fig. $1 \mathrm{a}, \mathrm{X}^{2}=5.67$, $1 \mathrm{df}, P=0.02$ ) and were significantly lighter in weight when compared to control queens (Fig. $1 \mathrm{~b}, t=2.06,23 \mathrm{df}, P=0.016$ ). The 1 and $10 \mathrm{mg} / \mathrm{kg}$ treatment groups were not significantly different than the controls in both the success rate of queen rearing and the resultant weight of queens reared.

\subsection{Commercial study}

The use of beeswax queen cups containing $1000 \mathrm{mg} / \mathrm{kg}$ of coumaphos resulted in complete

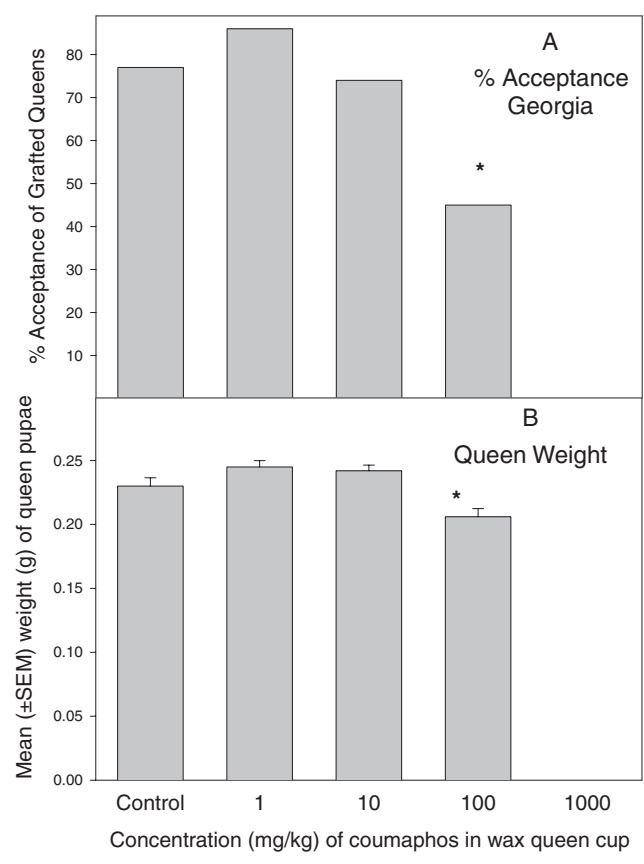

Figure 2. The percent acceptance (A) and weight (B) of pre-emergent queen honey bees reared in wax queen cups containing known concentrations of coumaphos. A total of 576 wax queen cups were tested in a single large trail using multiple starter and finisher colonies in July 2002, Claxton, Georgia. $*$ indicates significant differences from the control group $(P<0.05)$.

rejection of larvae grafted into the wax cups (Fig. 2a), similar to the Maryland study. Additionally, exposure to $100 \mathrm{mg} / \mathrm{kg}$ coumaphos resulted in a significant rejection rate of ca. $50 \%\left(\mathrm{X}^{2}=27.5,1 \mathrm{df}, P<0.0001\right)$ and queens that were significantly lighter $(t=2.07,22 \mathrm{df}$, $P=0.018$ ) than controls (Fig. 2b). Exposure to 1 and $10 \mathrm{mg} / \mathrm{kg}$ coumaphos resulted in queens that were not significantly different from controls for both the success rate of queen rearing and the resultant weight of queens reared.

\section{DISCUSSION}

The grafting of worker larvae into beeswax queen cups containing known concentrations 
of coumaphos resulted in varying rejection rates, including total rejection at $1000 \mathrm{mg} / \mathrm{kg}$ and ca. $50 \%$ rejection upon exposure to $100 \mathrm{mg} / \mathrm{kg}$, the U.S. tolerance level in beeswax (Federal Register, 2000). Several possibilities could account for the rejection grafted larvae including (i) poorly grafted or damaged larva; (ii) worker bees sensing something about the cell as abnormal and removing the contents, whether it be a healthy or unhealthy larva; (iii) direct toxicity to the larva from coumaphos in the wax; and (iv) other undetermined factors. While our experimental design does not allow us to determine which of these possibilities are responsible for the lack of completion of grafted cells, our finding that rejection rates increased in proportion with the concentration of coumaphos leads us to conclude that the coumaphos was acting in some fashion on the grafted larva. We can not determine if direct toxicity is involved or whether coumaphos had other affects on the developing larva that then caused attendant nurse bees to remove them from the cells. The end result was an aborted queen cell. Haarmann et al. (2002) discussed that miticides could act in two ways to affect queen rearing. Miticides could circulate in the colony on nurse bees attending the queen cells or they could be incorporated into the beeswax as the queen cell is being built. They could not determine which of the two methods or combination thereof were responsible for the effects they demonstrated, though our research indicates that wax residues alone can adversely affect queen rearing. In similar studies, Fries et al. (1998) examined the effects of miticides in beeswax on the parasitic mite Varroa destructor and found that most female mites died in worker cells produced on foundation containing at $100 \mathrm{mg} / \mathrm{kg}$ of coumaphos. Fries et al. (1998) also showed that the cocoon produced within the wax cell offers some level of protection for mites and presumably bees against wax residues.

Healthy queens are vital to maintain productive colonies. The current research clearly demonstrates that miticide residues in wax have the potential to adversely affect queen health. Earlier research to explore effects of the miticide fluvalinate on queens treated during shipment (Pettis et al., 1991) or colony level studies on brood production during chemical treatment (Westcott and Winston, 1999) failed to show effects. The current finding of high rejection rates and lighter queens at $100 \mathrm{mg} / \mathrm{kg}$ of coumaphos in beeswax and the finding of ca. $50 \mathrm{mg} /$ $\mathrm{kg}$ of coumaphos in beeswax combs (Nasr and Wallner, 2003) should serve as a warning of the potential problems with miticide accumulation in beeswax combs. Thus, beekeepers should consider rotating older combs out of their operation as a means to reduce the impact of miticide residues. Queen breeders should take caution to insure that wax used in making queen cups is pure and also not treat colonies during the time they are used for queen rearing (Rinderer et al., 1999). Finally, while we have come to depend on the excellent mite control these products provide we must use them sparingly to avoid contamination problems and reduce the risk of selecting for resistance.

\section{ACKNOWLEDGEMENTS}

We wish to thank K. Bohrer, O. Duncan, M. Hamilton, J. Kochansky and V. Williams of USDAARS and the entire staff of Wilbanks Apiaries, especially Dennis Oliver, for help in conducting these studies. We also wish to thank Dorset Hurley of the Sapeo Island National Estuarine Research Reserve, Georgia Department of Natural resources for support of these studies.

Résumé - Action du coumaphos sur l'élevage des reines d'Apis mellifera. L'usage au niveau mondial des acaricides pour lutter contre Varroa destructor Anderson \& Trueman dans les colonies d'abeilles domestiques (Apis mellifera L.) s'est accru. L'un des résultats est l'accumulation de ces acaricides dans la cire d'abeille avec des effets possibles létaux et sublétaux sur les individus au sein de la colonie. Nous avons réalisé des expériences afin de déterminer les effets de concentrations données de l'acaricide coumaphos dans les cupules en cire sur les reines élevées dans ces cupules. Nous avons testé des cupules en cire qui contenaient soit aucun résidu de coumaphos (témoins), soit 1, 10, 100,300, $600 \mathrm{ou} 1000 \mathrm{mg} / \mathrm{kg}$ de coumaphos. De jeunes larves d'ouvrières ont été transférées dans les cupules, placées dans des colonies orphelines, puis examinées $10 \mathrm{j}$ plus tard afin de déterminer le taux de rejet ou d'acceptation tel que l'indique une cellule royale mature operculée. Une autre étude a été faite dans une station d'élevage de reines commercial en Géorgie (USA). Dans les deux études, toutes les cellules ont été rejetées lorsqu'elles contenaient la concentration la plus forte $(1000 \mathrm{mg} / \mathrm{kg})$ et plus de $50 \%$ l'ont été à la concentration de $100 \mathrm{mg} / \mathrm{kg}$ (Figs. 1A et 2A). En outre les reines survivantes dans le traitement à $100 \mathrm{mg} / \mathrm{kg}$ étaient significativement plus légères que les reines témoins (Figs. 1B et 2B). Nous continuons à tester les effets sublétaux du coumaphos et d'autres acaricides sur le 
succès de l'accouplement des reines et sur la supersédure.

\section{élevage de reines / résidu / acaricide / coumaphos / cire d'abeille}

Zusammenfassung - Wirkungen von Coumaphos auf die Königinnenzucht bei der Honigbiene, Apis mellifera. Die weltweite Anwendung von Akariziden in Völkern der Honigbiene zur Bekämpfung von Varroa destructor hat zugenommen. Ein Ergebnis der Akarizidanwendung ist die Akkumulation dieser Verbindungen im Bienenwachs, durch die sich lethale oder sublethale Wirkungen im Volk entwickeln können. Hier beschreiben wir Versuche zur Bestimmung der Wirkung von Coumaphos auf Königinnen, die in Weiselnäpfchen aus Bienenwachs mit bekannter Konzentration gezüchtet wurden. Wir testeten Wachsnäpfchen ohne Coumaphos (Kontrolle) oder Näpfchen, die 1, 10, 100, 300, 600 und $1000 \mathrm{mg} / \mathrm{kg}$ Coumaphos enthielten. Junge Arbeiterinnenlarven wurden in die Weiselnäpfchen umgelarvt, in weisellose Völker gestellt und nach 10 Tagen wurde die Zahl der reifen, verdeckelten Weiselzellen zur Bestimmung der Annahme- bzw. Abweisungsrate überprüft. Zusätzlich wurde eine Untersuchung in einer kommerziellen Königinnenzuchtstation in Georgia (USA) durchgeführt. In beiden Studien wurden keine Zellen mit der höchsten Konzentration $(1000 \mathrm{mg} / \mathrm{kg})$ angenommen und nur $50 \%$ der Weiselzellen mit einer Dosis von $100 \mathrm{mg} /$ $\mathrm{kg}$ (Abb. 1A, 2A). Außerdem waren die Königinnen, die die Behandlung mit $100 \mathrm{mg} / \mathrm{kg}$ überlebten, signifikant leichter als die Kontrollköniginnen (Abb. 1B, 2B). Wir setzen die Tests über die sublethale Wirkung von Coumaphos und anderen Akariziden auf den Paarungserfolg der Königinnen und die Anzahl von Nachschaffungsköniginnen fort.

\section{Coumaphos / Königinnenzucht / Rückstände / Bienenwachs}

\section{REFERENCES}

Anderson J.F., Wojtas M.A. (1986) Honey bees (Hymenoptera: Apidae) contaminated with pesticides and polychlorinated biphenyls, J. Econ. Entomol. 79, 1200-1205.
Federal Register (2000) Coumaphos: pesticide tolerance for emergency action, 65(159), US Environmental Protection Agency, Washington, DC.

Floris I., Satta A., Garau V.L., Melis M., Cabras P., Aloul N. (2001) Effectiveness, persistence, and residue of amitraz plastic strips in the apiary control of Varroa destructor, Apidologie 32, 577-585.

Fries I., Wallner K., Rosenkranz P. (1998) Effects on Varroa jacobsoni from acaricides in beeswax, J. Apic. Res. 37, 85-90.

Haarmann T., Spivak M., Weaver D., Weaver B., Glenn T. (2002) Effects of fluvalinate and coumaphos on queen honey bees (Hymenoptera: Apidae) in two commercial queen rearing operations, J. Econ. Entomol. 95, 28-35.

Laidlaw H.H., Page R.E. Jr. (1997) Queen rearing and bee breeding, Wicwas Press, Cheshire, CT, $216 \mathrm{p}$.

Nasr M., Wallner K. (2003) Residues in Honey and Wax: Implications and Safety, Proc. of the North American Apicultural Research Symposium, Am. Bee J. 143, 322.

Pettis J.S., Wilson W.T., Shimanuki H., Teel P.D. (1991) Fluvalinate treatment of queen and worker honey bees (Apis mellifera L.) and effects on subsequent mortality, queen acceptance and supersedure, Apidologie 22, 1-7.

Rinderer T.E., De Guzman L., Lancaster V., Delatte G., Steltzer J.A. (1999) Varroa in the mating yard: I. The effects of Varroa jacobsoni and Apistan on drone honey bees, Am. Bee J. 139, 134-139.

Sanford M.T. (2001) Queen Problems, Apis newsletter (April), University of Florida, Gainesville, http:// apis.ifas.ufl.edu/apis_2001/apapr_2001.htm\#2 (accessed on 23 August 2004).

Sokol R. (1996) The influence of a multimonth persistence of Fluwarol in a hive of a honey bee colony, Med. Wet. 52, 718-720.

SAS (1988) SAS/STAT User's Guide, Release 6.03. Gary NC USA, 1001 p.

Wallner K. (1999) Varroacides and their residues in bee products, Apidologie 30, 235-248.

Westcott L.C., Winston M.L. (1999) Chemical acaracides in Apis mellifera (Hymenoptera: Apidae) colonies: do they cause nonlethal effects? Can. Entomol. 131, 1-9. 